\title{
ILCEA
}

Revue de l'Institut des langues et cultures

d'Europe, Amérique, Afrique, Asie et Australie

9 | 2007

L'implicite et les écrits de l'entreprise

\section{Because Crisis Happens}

Analysing the Implicit in Parmalat's Crisis Press Releases

\section{Paola Catenaccio}

\section{(2) OpenEdition \\ 1 Journals}

\section{Electronic version}

URL: http://journals.openedition.org/ilcea/716

DOI: 10.4000/ilcea.716

ISSN: 2101-0609

\section{Publisher}

UGA Éditions/Université Grenoble Alpes

\section{Printed version}

Date of publication: 15 December 2007

Number of pages: $153-170$

ISBN: 978-2-84310-104-5

ISSN: 1639-6073

\section{Electronic reference}

Paola Catenaccio, «Because Crisis Happens », ILCEA [Online], 9 | 2007, Online since 09 June 2010, connection on 01 May 2019. URL : http://journals.openedition.org/ilcea/716 ; DOI : 10.4000/ilcea.716

(C) ILCEA 


\title{
Because crisis happens
}

\section{Analysing the Implicit in Parmalat's crisis press releases}

\author{
Paola CATENACCIO \\ University of Milan (Italy)
}

\begin{abstract}
At the end of 2003, the Italian dairy giant Parmalat became embroiled in a financial scandal which, in a matter of weeks, led to temporary receivership and the initiation of bankruptcy procedures. Pressured by the international media (eager, in the wake of the scandals that had hit the American market a few years earlier, to point the finger at the perpetrators of financial crimes), as well as by investors and other stakebolders, Parmalat issued a series of press releases which document the unfolding of the crisis and illustrate the approach to crisis communication chosen by the company. This paper analyses the press releases in English (aimed, therefore, at the international public) issued by Parmalat between November 2003 and August 2004. The press releases are analysed both qualitatively, in a discourse-analytical perspective, and quantitatively, with the help of computerised routines (Wordsmiths Tools 4.0), with a view to identifying the main features of Parmalat's crisis communication strategy. The findings suggest that Parmalat did not have a clear communication strategy, and that textual (genre-related), lexical and syntactic choices conveyed implicitly the image of a company unwilling to engage dialogically with its stakebolders and unable to control the course of the events.
\end{abstract}

\section{RÉSUMÉ}

À la fin de 2003, le géant agroalimentaire italien Parmalt, se trouve entraîné dans un scandale financier qui, en quelques semaines, conduit à sa mise sous administration judiciaire et l'engagement des procédures de faillite.

Assailli par la presse internationale (impatient, dans le sillage des scandales qui ont frappé le marche américain quelques années auparavant, de débusquer les instigateurs des délits financiers), ainsi que par les investisseurs et d'autres parties prenantes, Parmalat publie une série de communiqués de presse qui documente le déroulement de la crise et illustre l'approche adoptée par la société en matière de communication en situation de crise.

Cet article analyse les communiqués de presse en anglais (destiné donc, à un public international) publiés par Parmlat entre novembre 2003 et août 2004. Ils font l'objet d'une analyse à la fois qualitative relevant de l'analyse du discours, et quantitative, à l'aide du concordancier Wordsmiths Tools 4.0, dans le but d'identifier les principales caractéristiques de la stratégie de communication de crise adoptée par Parmalat.

L'analyse indique que l'entreprise n'a pas adopté une stratégie de communication claire et les choix textuels (en rapport avec le genre), lexicaux et syntaxiques véhiculent, de manière implicite, l'image d'une entreprise incapable de maîtriser le cours des événements et peu disposée à engager le dialogue avec les parties prenantes.

Key words

Corporate communication, crisis communication, press releases.

Mots-clés

Communication de l'entreprise, communication de crise, communiqués de presse. 
At the end of 2003, the Italian dairy giant Parmalat - a company with branches and subsidiaries all over the world - was hit by a crisis of unprecedented dimensions which, in a matter of weeks, led to temporary receivership and the initiation of bankruptcy procedures. The crisis commanded the attention of the international press not only because of the global level of the company's operations, but also because it came in the wake of the financial scandals that hit the US market in 2001-2002, when companies such as Enron, Andersen, and WorldCom had become embroiled in crises of a similar nature, revealing just how dangerous creative finance can be.

Because of these precedents, the Parmalat crisis - "Enron à la parmigiana", as it was dubbed by Newsweek - attracted attention worldwide. This meant that all the statements and information made available by the company in respect of the crisis were bound to be scrutinised by the international media, as well as by the multiple stakeholders who had an interest in the company.

The importance of - and difficulties inherent in - strategic crisis communication cannot be overemphasised. As communication and organisational scholars have long recognised (cf. Fearn-Banks 1996), regardless of the nature of the crisis, communicating to key publics is crucial if a company's credibility is to be preserved ${ }^{1}$. In so far as a crisis can be defined, following Heath (2004:167-168), as "a predictable event that occurs at an unexpected time and threatens the well being of stakeholders and stakeseekers (key publics) [...], it challenges the ability of the organization to enact the narrative of continuity through constructive change to control the organization's destiny". In this sense, a crisis represents a "rhetorical exigency" which "takes the form and substance of a narrative, a series of events that is expected to represent a factually accurate, coherent, and probable account for the event and its proper resolution".

1. The Enron scandal and the spate of other crises (on a smaller scale, but no less relevant) which occurred just after the turn of the millennium gave rise to a renewed interest in crisis communication which resulted in the publication of several studies on the topic. Most of them build on previous communication-theory-based research (cf. Barton 1990, 1993; Sturges 1994; Benoit/Brinson 1994; Coombs 1998; Fishman 1999; Jones/Jones/Little 2000; Nakra 2000; Cowden/Sellnow 2002; Mahon/Wartick 2003; George/Evuleocha 2003; Laurence 2004; Reber 2006) often taking a rhetorical, content analysis approach on the basis of Benoit's (1995) classic study and subsequent applications (Benoit 1997; Benoit/Czerwinski 1997). An increasingly large body of literature is also being developed which looks at crisis communication from rhetorical perspectives other than Benoit's (see especially Millar/Heath, 2004), occasionally with an emphasis on interdisciplinary approaches (Jacobs 2001). Linguistics-oriented studies are still rare, although there are a few (most notably Coombs 1995; Hobbs 1995; Jacobs 1999). 
In this narrative (re)construction, a key role is played by press releases (cf. Gilpin 2006), a form of "mediated discourse" (Jacobs 1999) through which organizations communicate newsworthy information to the media and, through the media, to the general public ${ }^{2}$. The main purpose of press releases is to be reproduced as faithfully as possible by journalists, thus attaining external sanction and thereby enhancing the credibility of both the "story" and the company itself.

The kind of external sanction provided by the reproduction of the "licensed" version of the story in the media is all the more important in times of crisis, when the company's interpretation of the events will likely be in competition - and often in conflict - with alternative interpretations put forward by competing voices (cf. Holder 2004: 56). In these cases, the ability to persuade the audience that one's version of the events is to be preferred is of paramount importance.

In light of the above, this paper analyses Parmalat's crisis press releases with a view to tracing the discursive, textual, and lexico-syntactic patterns that characterise them and assessing their effectiveness in a crisis-management perspective. Particular attention will be devoted to the meanings and attitudes implicitly conveyed by textual features and other linguistic choices, and to their likely impact on the overall persuasiveness of the press releases under investigation.

The study will rely on recent research on the genre of the press release $^{3}$ (Jacobs 1999, McLaren/Gurău 2005, Catenaccio, unpublished

2. In the last few years the communicative revolution brought about by the advent of the World Wide Web has radically changed the participation framework of many genres that have "migrated" to the web (cf. Garzone 2007), including the genre of the press release (cf. Catenaccio 2007). In fact, press releases are now often seen - and used - by public relations practitioners as direct marketing tools (cf. Aronson/Spetner/Ames 1998; Fletcher 2004; McIntyre 1992), to the extent that a recent genre-based study of the press release sees it as mainly addressed at investors (McLaren/Gurău 2005); however, journalists remain a primary audience for press release writers, all the more so in the context of a crisis characterised by extensive media interest such as the one under discussion.

3. Besides the obvious importance of the genre for communication scholars, in recent years press releases have also attracted the attention of linguists, initially because of their "preformulated" nature (Jacobs 1999), which makes them particularly suited to pragmatic analyses, and later in a variety of perspectives, including but not limited to ethnographic studies (Sleurs/Jacobs/van Waes 2003, Sleurs/Jacobs 2005) and inquiries into the textual outcomes of press releases in the media (Lenaerts 2002, Pander Maat 2007, Catenaccio, 2006). In contrast to the body of press release research developed during the last few years, which relies on the assumptions that press releases constitute a genre, Lassen (2006) has recently questioned the genre status of press releases on the basis of their varying rhetorical purpose. Lassen argues that the press release may be better accounted for by considering it as a media channel, but acknowledges that it can be seen "as a genre at a very broad level" (2006: 527), suggesting, following Fairclough (2003) that is should be categorised as a disembedded genre. In this paper I will assume that press 
manuscript) combined with insights from crisis communication and reputation management studies. With reference to recent research on press releases, preliminary considerations will be made in respect of the presence of the typical features of the genre in the texts selected for the analysis. Secondly, the focus of the investigation will move on to textual organization as a framing device involving self- and other-representation, bearing in mind that not only the persona of the organization, but also that of the stakeholders is implicitly or explicitly framed in crisis communication in general, and in press releases in particular (Heath/Millar, 2004: 15). This approach will then be further expanded to include microtextual analysis, and attempt to identify recurrent elements which point in the direction of a strategic use of specific lexical items and their combination in syntactic patterns. Finally, the different levels of analysis will be integrated, with a view to providing a comprehensive account of the linguistic strategies deployed by the company in its crisis response and assessing its effectiveness.

\section{Corpus and method}

The present study is based on a small collection of 59 press releases in English ${ }^{4}$ issued by Parmalat between November 2003 and August 2004. It was decided to base the analysis on English-language press releases because the international dimension of the Parmalat crisis demanded that crisis communication be addressed to international, as well as national, stakeholders and journalists, and required therefore that it be geared to meet the needs and expectations of an international audience.

Although the focus of this research is on crisis-related press releases, the analysis includes some press releases issued before the crisis proper (i.e. the beginning of official investigations on the part of the authorities), starting from the ones dealing with what at the time could still be treated as rumours and allegations, but which, nonetheless, represented a threat to the company's reputation. Thus, in chronological terms, it was decided to start the selection from the first press release mentioning the Epicurum fund, which was later to be recognised as the financial operation that triggered the collapse of the company. This press release,

releases do in fact constitute a genre, on the basis of their grounding in a recognised social practice for a macropurpose that combines informative and promotional objectives (Catenaccio unpublished manuscript).

4. All press releases in English were published at the same time as press releases in Italian; all press releases appear in the Investor Relations page of the Parmalat website in both languages. 
issued on November 11, 2003, contains a strong defensive statement aimed at restoring wavering investor confidence, which gives an indication of the potential seriousness of the allegations it attempted to counteract. It precedes by a few weeks the actual crisis, which resulted in the initiation of bankruptcy proceedings on January 7th, 2007. Immediately before and after the bankruptcy filing, communication with the press via press releases intensified, with press releases being issued almost every day and on occasion even twice daily; after a while, once it had become clear that no recovery was possible, press releases decreased in frequency. A few weeks into receivership ("extraordinary administration" in Italian "amministrazione straordinaria") the situation had somewhat "normalised"; by August press releases had decreased in frequency, and they were clearly no longer dealing with a crisis situation, but with the aftermath of the crisis.

As regards press release selection, all press releases published within the timespan described above were selected with the exception of those notifying of the publication of quarterly results ( 3 in total). These financial press releases were excluded because they made no reference to the crisis and added extremely limited commentary to the key financial indicators published. It should also be noted, moreover, that on the corporate website a clear distinction is made between the press releases issued before and after the beginning of extraordinary administration. All press releases issued before January 7th, 2001 were issued by Parmalat Finanziaria S.p.A.; from January 7th, 2004 onwards, press releases were issued by Parmalat Finanziaria S.p.A. in amministrazione straordinaria ("under extraordinary administration"). Despite this highlighting of the discontinuity before and after the crisis, the press release format, style and deployment of genre-specific features remained the same (as shall be seen in greater detail below). For this reason, the author felt justified in choosing to consider the two subsets jointly.

Because the aim of the study was to integrate different perspectives, a combination of approaches was used. In particular, the crisis press releases were first analysed as instances of the macro-genre of the press release, with a view to verifying if, and to what extent, they displayed the salient features of the genre itself; secondly, the study focussed on selfrepresentation, relying for this purpose on tools drawn from discourse analysis (Hodge/Kress 1979) and systemic approaches (Halliday 1985; Martin 1992), as well as on computerised routines (Wordsmith Tools 4.0), thus combining qualitative and quantitative methodologies in an attempt to apply corpus linguistics techniques to text analysis (cf. Flowerdew 1998). 


\section{Crisis communication and persuasion}

In times of crisis companies need to communicate with their publics swiftly and effectively, and they often do so by talking to the media. Other means of communication are possible (such as advertising - cf. Cowden/Sellnow 2002; Blaney/Benoit/Brazeal 2002, direct mail or multiple-public communication via corporate websites - cf. DiNardo 2002; Greer/Moreland 2003), but media communication remains a priority, especially in light of the power of the media to influence public opinion.

It has been pointed out above that companies facing a crisis need to restore - both factually and discursively - the order which the crisis event has disrupted, and that to do so they must persuade their key publics that their version of the events is credible and accurate. Of course, extra-linguistic elements contribute to credibility and, therefore, persuasion. If a company is known to be lying, no amount of communication is going to make its version of the events credible. In general, however, it may be argued that all crisis communication is inherently persuasive in nature, not necessarily because it succeeds in persuading, but because its "persuasive intention can be taken for granted" (Jucker 1997: 123$)^{5}$.

But what are the linguistic features that make a text persuasive? As Virtanen and Halmari (2005: 6-14) point out, persuasion is interactive in nature - it implies a dialogic relationship with the audience, be it real or envisaged - and may be pursued through different linguistic means, not all of them explicit. Genre-specific expectations (cf. Swales 1990; Bhatia 1993), for instance, contribute implicitly to the persuasiveness of a text, but the way in which they do so is not pre-ordained. In fact, persuasion may be achieved both by minimising and by maximising the gap between the text and the expected prototype: a text may be persuasive because it does everything it is expected to do according to the prevailing norm, but it may be persuasive also because it distances itself from the norm (as is the case, for instance, with the genre of the advertorial, whose persuasiveness relies on its lack of resemblance to the advertisement). The same can be said of discourse expectations, and of the linguistic realization of genre moves and discursive patterns in texts.

These general considerations can be used as a starting point for an analysis of the communicative strategies deployed by Parmalat in its crisis press releases. In so far as persuasion is dialogic in nature, what evidence of dialogic involvement do the press releases display? Bearing in

5. On persuasion see also Halmari-Virtanen (2005); on persuasion and informativity in press releases cf. Catenaccio (unpublished manuscript). 
mind that these were made available in English (therefore implicitly acknowledging an international audience), do the press releases under consideration display the features which are typically expected (by all stakeholders, but in particular by members of the international press) of this kind of text? If not, what are the consequences in terms of communication effectiveness and - presumably - persuasiveness?

\section{The genre of the press release}

The press release is one of the most common genres used in media communication. Press releases are not only crisis communication tools; rather, they are primarily tools used for ordinary communication with the media, and through the media with the public. As a rule, they are issued whenever a company needs to communicate a piece of newsworthy information to the public at large, often in an attempt to gain thirdparty endorsement through media coverage. As they aim at being reproduced as extensively and faithfully as possible, press releases are characterised by what Jacobs (1999) calls preformulating features - i.e. metapragmatic features designed to facilitate the copying out of (possibly large) chunks of text for use in news articles. Among these features, the most important are:

1. third person self-reference: even though the sender of the message is the company, first-person reference is rare in press releases; generally, the company is referred to in the third person, in order to objectify statements and make them easier to reproduce.

2. use of semi-performatives (third-person performatives): a typical press release opening reads: "Company X announced today ...", where announced is a semi-performative in that it has a performative function (the press release is the announcement), but also a reporting function;

3. use of pseudoquotes: press releases typically include pre-approved fictional (but presented as if they had been actually uttered) quotes attributed to management figures and designed ad boc to be quoted by journalists.

In addition, press releases appear to have a fairly standardised textual organisation (McLaren/Gurău $2005: 16$; Catenaccio unpublished manuscript) ${ }^{6}$ with clearly recognisable recursive moves (see Figure 1).

6. Although independently elaborated, the two models show remarkable similarities; however, some of the features that McLaren and Gurău include in the move structure of the press release are considered by Catenaccio as separate elements. 


\section{Company logo}

"Press release"

Contact details

(name, phone number)

\section{Headline}

Date

"for immediate release"

Lead

Expansion

Pseudoquotes

Boilerplate description

Figure 1

Among these, Catenaccio (unpublished manuscript) distinguishes between core and peripheral press release features. Peripheral features include contact details, company logo, "press/news release" and "for immediate release" 7 writings : these items are essential to the identification of the press release as such, but marginal in terms of their contribution to press release content ("the story"). As regards the body of the press release, it is organised according to the "inverted pyramid" structure typical of news articles, with a headline and lead followed by positively connotated expansions and one or more suitable "pseudoquotes" where most of the evaluative language concentrates (cf. Pander Maat 2007) and where the company's "personal voice" can make itself heard. Finally, another typical press release feature is the boilerplate description of the company, which can be defined as a boundary move between core and periphery, both in terms of layout (it is normally located after the body of the press release) and informative content (it does not add anything to the "story", but it provides information on the company that may or may not be used by journalists and/or needed by other stakeholders).

7. "For immediate release" alternates with "embargoed until"; the formulas refer to the time when the content of the press release - which needs to be communicated to the press in advance - can be made public. Recently, as press releases have become increasingly addressed to the general public and made available on corporate websites, these formulas are being dropped. 
In light of this discussion, it is therefore possible to verify if and to what extent the press releases issued by Parmalat match the expectations raised by the genre of the press release in its prototypical form.

\section{Parmalat crisis press releases}

\section{Peripheral features}

As far as peripheral features are concerned, the Parmalat press releases (cf. Figure 2) exhibit the customary "press release" formula which constitutes an explicit indication of the nature of the text which displays it. By contrast, they do not carry the other customary formula ("for immediate release"), but this feature has recently become optional (cf. note 7

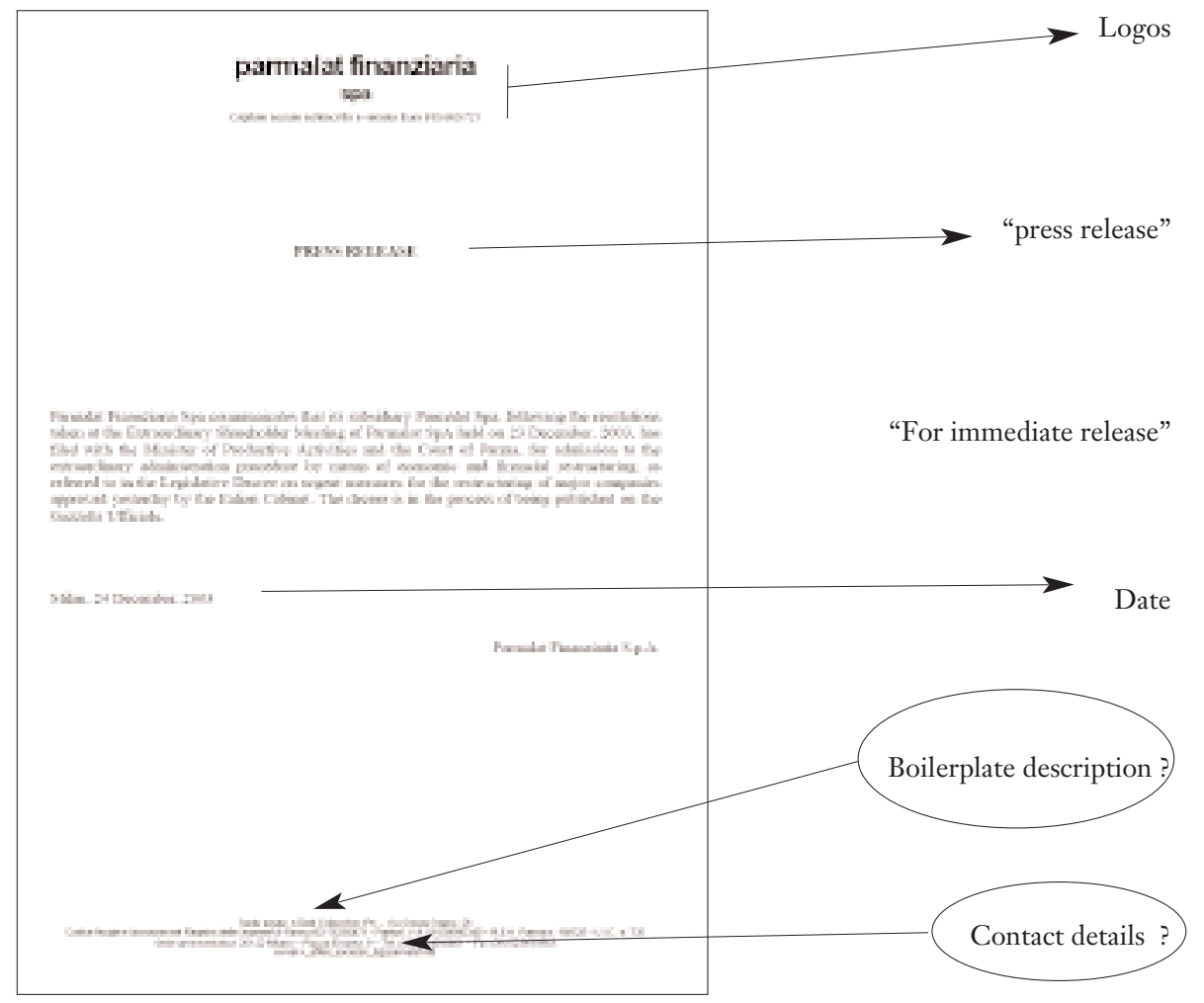

Figure 2 
Moving on to contact details and boilerplate information, it is evident that these do not appear in the press releases, or, rather, they do so only in part. For what concerns contact details, the company does not offer any specific name or phone number, but rather embeds the information in a small-print formula which appears in the page footer and which contains several other details, most of which are required by Italian law to appear in corporate documents. The text appearing in the footer reads as follows:

Sede legale: 43044 Collecchio (Pr) - Via Oreste Grassi, 26

Codice fiscale e iscrizione nel Registro delle Imprese di Parma 00175250471 -

Partita I.V.A. 01938950340 - R.E.A. Parma n. 188325 - U.I.C. n. 730

Sede amministrativa: 20122 Milano - Piazza Erculea, 9 - Tel. (39) 02.8068801 -

Fax (39) 02.8693863

e-mail x_affari_societari_it@parmalat.net

The footer appears unchanged in the Italian and English press releases; presumably this is due to the fact that it represents the standard formula for all corporate correspondence. However, the absence of a dedicated phone number for press inquiries suggests that the company may not be particularly forthcoming with additional information. Although this aspect of Parmalat press releases was by no means confined to the ones issued during the crisis, it may be taken to imply a lack of attention to media relations, especially in respect of foreign media.

Similar considerations can be made about boilerplate information, a feature which is also noteworthy for its absence in the Parmalat press releases. Nowhere in the press release is it stated what line of business the company is in; again, this type of information may be redundant for Italian journalists, but may have been relevant for international audiences $^{8}$, and failure to provide it suggests disregard on the part of the company for the members of the international press.

\section{Preformulation and other genre-specific features}

The preformulating features identified by Jacobs (1999) and described above are third-person self-reference, semiperformatives and pseudoquotes. While typically using third person-self reference and employing semiperformatives, the Parmalat press releases display a notable paucity of pseudoquotes. Even on the rare occasions in which a comment is offered, it is quoted as reported speech, as in the example below:

8. In this respect, it is worth noticing that in Parmalat-related articles in English-language media, reference to the company was usually accompanied by an appositional phrase (such as "the Italian dairy giant") clarifying its role and business position in the country. 
Based on the information communicated by the Chairman, Cav. Lav. Calisto Tanzi, today's Board of Directors' meeting acknowledged:

- the difficulties in liquidating Parmalat's investment in the Epicurum Fund, which should have taken place on December 4, 2003, and the resulting delay in payment requested by the Epicurum Fund (which has in the meantime placed itself in liquidation), according to a repayment schedule that has yet to be defined;

- the decision to delay repayment of $€ 150$ million in bonds maturing on December 8, 2003 until the last possible deadline of December 15, 2003, in accordance with the regulations for bonds issued by Parmalat Finance Corporation.

In view of the situation described by the Chairman, and with the aim of giving the market and financial institutions a sign of the Group's willingness to find a transparent solution to what has recently become an increasingly difficult situation, the Board has engaged Mr. Enrico Bondi as a technical consultant, to draw up an eventual plan for the Group's industrial and financial restructuring.

The Chairman also announced that, as of December 8, 2003, Mr. Luciano Del Soldato has resigned his seat on the Board of Directors and his position as CFO.

Cav. Lav. Calisto Tanzi reiterated the Tanzi family's commitment, during this difficult time, to the Parmalat Group's shareholders, bondholders, staff, customers and suppliers to preserve the Company's value in the interests of all its stakeholders.

Milan, December 9, 2003

The choice to use quotations extremely sparsely reduces significantly the possibility of having the company's views reproduced in the media, as quotations are the part of the press release which is most likely to be reproduced verbatim (Jacobs 1999). It also limits the possibility of relying on pathos for persuasive purposes, and suggests a reluctance to engage in interpersonal communication, substantially diminishing the dialogic component of the press release.

\section{Moves and textual organization}

When considering the internal organization of the press releases and, in particular, the presence in their bodies of the main moves described in $\$ 3$, the gap between prototypical press releases and the press releases issued by Parmalat becomes even more evident.

To begin with, Parmalat's press releases seldom have a headline. They usually start straight from the lead, and move on to providing some details of the information announced, with little commentary added. Moreover, the evaluative component which is often a key part of the press release is almost entirely absent from most of the releases issued by the Italian company. In this respect, the press release quoted in 
$\$ 4.2$ above is an exception: it attempts to portray Parmalat in a positive light by describing it as willing "to find a transparent solution to [...] an increasingly difficult situation", and by stating its commitment to the company's stakeholders. The majority of the press releases, however, do not contain any kind of positive evaluation'; in fact, they do not even attempt to convey the company's active involvement and commitment to overcome the crisis. The press release reproduced below provides a clear example of this:

\section{PRESS RELEASE}

Parmalat Finanziaria S.p.A. communicates that on 17 December 2003 Bank of America N.A., New York Branch, informed Grant Thornton, the auditor of Bonlat Financing Corporation, a company based in the Cayman Islands and part of the Parmalat Group, that it does not have "an account" in the name of Bonlat.

Further, Bank of America denied the authenticity of a document dated 6 March 2003 that certified the existence of securities and liquidity amounting to approximately $€ 3,950$ million as at 31 December 2002 relating to Bonlat. This document was taken as the basis for the certification of Bonlat's 2002 accounts.

The letter from Bank of America follows a request for information made on the same date by Grant Thornton.

The above information was provided to Parmalat by Consob in the late afternoon of 18 December 2003.

Further to the above, the Company has initiated the necessary urgent verifications.

The Company also informs that the Chairman has called an Extraordinary Meeting of the Board of Directors to take place in the late afternoon of today with "Chairman's Communication" on the agenda.

Milan, 19 December 2003

The press release was issued at a crucial time for Parmalat, as the nonexistence of the account had a snowballing effect. The absence of a headline makes it difficult for the reader to immediately identify the main news. The release starts with a syntactically convoluted lead ("Parmalat

9. It should be noted that while the lack of any positive evaluation may appear understandable, given the nature of the circumstances that prompted the press releases, this is not always necessarily the case with crisis-related press releases. The releases issued by Enron during the crisis in which the American company became embroiled, for instance, show that positive evaluation may, in fact, be included even in documents announcing negative events (cf. Catenaccio unpublished manuscript; Catenaccio in press). 
Finanziaria S.p.A. communicates ...") in which it is hard to trace the complex network of relationships existing between the various actors mentioned (Parmalat, Bank of America, Grant Thornton, Bonlat). The main information (the non-existence of the Bonlat account) is buried in a doubly hypotactic construction made more complex by the inclusion of two interlocking definitions embedded in the first secondary clause. The company's reaction is stated in neutral terms; the use of "urgent" gives an indication of the growing pressure (but does not give an indication of the company's attitude). No comment is provided, either in positive or negative terms. Textual organization and thematic structure do not offer an interpretive key for the events reported: these are related in strictly chronological order, and no attempt is made to give salience to the company's response. Significantly in this respect, in the press release quoted above, "Parmalat" occurs in subject position only three times, two of which in connection with reporting verbs, and only once in association with a verb indicating a material process (bas initiated); in other words, Parmalat reports other parties' actions and statements, rarely saying (and, even more rarely, doing) something in its own right.

\section{Microlinguistic analysis}

The results of the macrotextual analysis reported above convey the image of a company reluctant to engage in a dialogic relationship with its key publics and inclined to chronicle, rather than actively face, the crisis in which it found itself enmeshed. The next step in the investigation was to verify whether microlinguistic data confirmed this initial impression based mainly on structural aspects. To do so, the press releases (suitably edited in order to confine the analysis to press release content, with the exclusion of peripheral features) were analysed quantitatively using the wordlist and concordance functions of Wordsmith Tools 4.0.

The edited Parmalat corpus amounted to 12,783 tokens, with a standardized type/taken ratio of 36.60. The wordlist generated for the corpus revealed - not surprisingly, given the nature of the corpus - a high frequency of self-referential words: apart from the company name, the five most frequent lexical words ${ }^{10}$ are extraordinary $(0.79 \%)$, finanziaria $(0.63 \%)$ (part of the company name: Parmalat Finanziaria), group $(0.63 \%)$, administration (0.62\%), and company (0.59\%), followed by financial (50\%), fund (49\%) and board (46\%). As for lexical verbs, they

10. With the exclusion of articles, demonstratives, etc. 
rank very low in the frequency list: the most frequent one is communicates $(0.34 \%)$, which is the verb used by default to introduce press release content, and is always predicated of the company. The other most frequent lexical verb forms are made, expected, provided, received and requested $(0.10 \%)$.

Concordances generated for these verb forms show that made, expected and provided nearly always occur in agentless passive constructions (very frequent in the corpus, with 90 occurrences). As for received and requested, the former is usually predicated of Parmalat, as shown in the example below:

(1) With this press release Parmalat Finanziaria represents to have received last night (late evening American time) a formal communication from the openended fund Epicurum based in the Cayman island complaining with undertones of preoccupation and strong disappointment, of the grave situation which was created in Italy and afterwards in other countries with regard to and following some press articles and releases from various sources also of financial nature.

In this example Parmalat is the grammatical subject of the material process described by the verb receive, but representationally it appears as the beneficiary of the process. Similarly, with reference to requested, this verb form is generally used to refer to requests made in respect of the admission to extraordinary administration of companies belonging to the Parmalat Group, as exemplified in the following passage:

(2) Parmalat Finanziaria Spa communicates that Dr. Enrico Bondi, Extraordinary Commissioner of its subsidiary company Parmalat Spa, today requested that the Minister of Productive Activities admit Parmalat Finanziaria SpA, Eurolat Spa and Lactis Spa to the Extraordinary Administration procedure referred to under article 3, section 3 of Legislative Decree no. 347 of 23 December 2003. [June 16, 2004]

In this case Parmalat is once more at the receiving end of the process described, so that the company once again comes across as being entirely deprived of agency.

Other cases - besides those discussed in examples 1 and 2 - in which Parmalat appears in subject position can be split into two different categories. On the one hand, there are several examples in which the company appears engaged in an operation of a purely discursive nature aimed at confuting rumours and allegations:

(3) Parmalat intends hereunder to provide additional information

(4) Parmalat Finanziaria wishes to clarify a number of points

(5) Parmalat Finanziaria wishes to emphasise the strength

(6) The Parmalat Group wishes to specify the terms of the participation agreement

(7) Parmalat Finanziaria states that the Epicurum Fund did not liquidate Parmalat's investment 
On the other, there are a few instances in which Parmalat acknowledges, without trying to refute, the extent of the crisis, and announces its intended course of action:

(8) Parmalat Finanziaria has decided to accept the request of liquidation of its participation in the Fund

(9) Parmalat Finanziaria will reserve its action

(10) Parmalat has noted the above and has reserved any decision

(11) Parmalat S.p.A. intends to act to preserve the value of the Company and its brands

Notice that in one case (8) the decision implies the acceptance of a proposal; in two more (9 and 10) no decision is made; and in the last case, the pledge to preserve the value of the company for the benefit of its stakeholders is only half-heartedly expressed by means of the verb to intend, which carries a deontic meaning but does not have the same force which would be conveyed, for instance, by the use of will. Thus, once again Parmalat comes across as being prey to events, a company sinking deeper and deeper into increasingly murkier waters, unable to make any move - albeit only of a discursive nature - to try to salvage its reputation.

Crisis communication is no doubt one of the areas of corporate communication most fraught with challenges and difficulties.

In the case of Parmalat, these general difficulties were compounded by the lack of a clearly defined communication strategy, which was highlighted by the analysis.

First of all, in so far as the Parmalat press releases lacked some of the moves - both core or peripheral - which are distinctive of the genre, they only partially met the expectations typically raised by it. To the extent to which crisis communication is expected to be clear, complete and timely, failing to provide quotes attributed to the management, or to supply the name of a person internal to the organization to whom inquiries may be directed is likely to have impacted negatively on the public perception of the company's credibility. Secondly, from the point of view of textual organization, the purely chronological narrative approach adopted by Parmalat proved ineffective for a successful portrayal of the company as one that was willing to face the crisis and capable of doing so. By presenting the company as re-active, rather than proactive, the press releases encouraged a reading of the crisis which showed Parmalat as unable to keep abreast of the events. This was confirmed, at a microtextual level, by a prevalence of the passive voice without explicit agent, which had the effect of representing the crisis as 
something with a life of its own, over which the company was unable to exercise any control. This inability to restore order was further emphasised by the lexical choices made in respect of the actions predicated of Parmalat, which was consistently portrayed as a recipient or an observer - in both cases, as a subject deprived of agency.

The image of Parmalat as a company unwilling to communicate with journalists and stakeholders, passive in its approach to crisis and incapable of conveying a positive self-representation is not, of course, exhibited explicitly in the press releases. Rather, it is codified implicitly in the textual choices made in them. The lack of pseudoquotes is significant because the press release as a genre implies quotes: an expert reader will expect to find a quote in a press release, and will interpret its absence as meaningful. Similarly, choices made in respect of textual organization and representational patterns betray - rather than voluntarily disclose attitudes, approaches, and, ultimately, self-image. In so far as language is used to exercise control over reality - and it certainly is in crisis communication - exercising control over what is implicit in language is a strategically crucial task.

\section{References}

Aronson M., Spetner D., Ames C., The Public Relations Writer's Handbook, San Francisco, CA, Jossey-Bass, 1998.

Barton L., "Crisis management: Selecting communication strategy", Management Decision, 28, 6, 1990, pp. 5-8.

Barton L., Crisis in organizations: Managing and communicating in the heat of chaos. Cincinnati, OH, South-Western, 1993.

Benoit W.L., Brinson, S., "AT\&T: Apologies are not enough", Communication Quarterly, 42, 1, 1994, pp. 75-88.

Benoit W.L., Czerwinski A. (1997), “A critical analysis of USAir's image repair discourse", Business Communication Quarterly, 60, 3, 1997, pp. 38-57.

Benoit W.L., "Image repair discourse and crisis communication", Public Relations Review", 23, 2, 1997, pp. 177-186.

-, Accounts, excuses and apologies: A theory of image restoration strategies, Albany, State University of New York Press, 1995.

Bhatia V.K., Analysing Genre - Language Use in Professional Settings, London, Longman, 1993.

Blaney J.R., Benoit William L., Brazeal L.M., "Blowout! : Firestone's image restoration campaign", Public Relations Review, 28, 3, 2002, pp. 379-392.

Catenaccio P., "La comunicazione in tempo di crisi: i comunicati stampa di Enron e Parmalat", in Calvi, M. V., Mapelli, G., Santos, J. (a cura di), Lingue e culture nella comunicazione economica e commerciale, Milano, Franco Angeli (in press).

-, "New(s) genres and discursive identity: The changing face of press releases in the age of the Internet", in Garzone, G., Poncini, G., Catenaccio, P. (eds) 
Multimodality in Corporate Communication. Web Genres and Discursive Identity, Milano, Franco Angeli, 2007, pp. 55-71.

-, "'Looking beyond today's headlines': The Enron crisis from press release to media coverage", in Bondi, M., Bamford J. (a cura di) Managing Interaction in Professional Discourse. Intercultural and Interdiscoursal Perspectives, Roma, Officina Edizioni, 2006, pp. 159-172.

-, "Press releases as a hybrid genre: addressing the informative/promotional conundrum", unpublished manuscript.

Coombs W.T., "Choosing the right words: The development of guidelines for the selection of the 'appropriate' crisis-response strategies", Management Communication Quarterly, 8, 1995, pp. 447-476.

—, "An analytic framework for crisis situations: Better responses from a better understanding of the situation", Fournal of Public Relations Research, 10, 3, 1998, pp. 177-191.

Cowden K., Sellnow T.L., "Issues advertising as crisis communication: Northwest Airlines's use of image restoration strategies during the 1998 pilots' strike", The Fournal of Business Communication, 39, 2, 2002, pp. 193-219.

DiNardo A. M., "The Internet as a crisis management tool: a critique of banking sites during Y2K", Public Relations Review, 28, 3, 2002, pp. 367-378.

Fairclough N., Analyzing Discourse: Textual Analysis for Social Research. London, Routledge, 2003.

Fearn-Banks K., Crisis Communications: A Casebook Approach, Mahuah, N.J., Laurence Earlbaum, 1996.

Fishman D.A., "ValuJet Flight 592: Crisis communication theory blended and extended" Communication Quarterly, 47, 1999, pp. 345-375.

Fletcher P., An editor's guide to perfect press releases. The key to free success for your organization or business, Charleston, SC, BookSurge, 2004.

Flowerdew, L., "Corpus linguistics techniques applied to textlinguistics", System, 26, 4, 1998, pp. 541-552.

Garzone, G., "Genres, multimodality and the World Wide Web: theoretical issues", in Garzone, G., Poncini, G., Catenaccio, P. (eds) Multimodality in Corporate Communication. Web Genres and Discursive Identity, Milano, Franco Angeli, 2007, pp. 15-30.

George A.M., Evuleocha, S., "Denials, excuses, justifications and apologies: Restoring tarnished reputations after the year of corporate malfeasance. What worked and what didn't", Proceeding of the 2003 Association for Business Communication Annual Convention, 2003, pp. 1-17.

Gilpin D., "Narrating the organizational self: reframing the role of the news release", unpublished manuscript, 2006.

Greer, C.F., Moreland K.D., "United Airlines' and American Airlines' online crisis communication following the September 11 terrorist attacks", Public Relations Review, 29, 4, 2003, pp. 427-441.

Halmari H., Virtanen T. (eds), Persuasion across genres, Amsterdam / Philadelphia, John Benjamins, 2005.

Halliday, M.A.K., Introduction to Functional Grammar, London, Edward Arnold, 1985.

Heath R.L., "Telling a Story: A Narrative Approach to Communication During a Crisis", in Millar, D.P., Heath, R.L. (eds.), 2004, pp. 167-187.

-, Millar D.P. "A rhetorical approach to crisis communication: Management, Communication Processes and Strategic Responses", in Millar, D.P., Heath, R.L. (eds.), 2004, pp. 1-18. 
Hobbs J.D., "Treachery by any other name: A case study of the Toshiba public relations crisis", Management Communication Quarterly, 8, 1995, pp. 323-346

Hodge R., Kress G., Language as Ideology, London and New York, Routledge, 1979.

Holder T.L., "Constructing Response During Uncertainty: Organizing for Crisis", in Millar D.P., Heath R.L. (eds.), 2004, pp. 51-61.

Jacobs, G., Preformulating the News: An Analysis of the Metapragmatics of Press Releases, Amsterdam/Philadelphia, John Benjamins, 1999.

-, "What's in a Crisis? A critical look at the field of crisis communication", Document Design, 2, 3, 2001, pp. 225-235.

Jacobs G., Van Waes L. (eds.), The Pragmatics of Crisis, Special issue of Document Design, 2, 3, 2001.

Jones T.M., Jones B.H., Little P., "Reputation as reservoir", Corporate Reputation Review, 3, 1, 2000, pp. 21-29.

Jucker A.H., "Persuasion by inference: Analysis of partypolitical broadcast", in Blommaert J., Bulcaen C. (eds), Political Linguistics, Belgian Journal of Linguistics, 11, 1997, pp. 121-137.

Lassen I., "Is the press release a genre? A study of form and content", Discourse Studies, 8, 4, 2006, pp. 503-530.

Laurence A., "So what really changed after Enron?", Corporate Reputation Review, 7, 1, 2004, pp. 55-63.

Lenaerts, G., "In Pursuit of the Functional Quality of Political Press Releases", Document Design, 3, 2002, pp. 210-223.

Mahon J.F., Wartick, S.L., "Dealing with Stakeholders: How Reputation, Credibility and Framing Influence the Game", Corporate Reputation Review, 6, 1, 2003, pp. 19-35.

Martin, J., English Text: System and Structure, Amsterdam, Benjamins, 1992.

McIntyre C. Writing effective news releases... How to get free publicity for yourself, your business or your organization, Colorado Springs, Co Piccadilly books, 1992.

McLaren, Y., Gurău, C., "Characterising the Genre of the Corporate Press Release", LSP and Professional Communication, 5, 1, 2005, pp. 10-30.

Millar D.P., Heath R.L. (eds.), Responding to Crisis. A Rhetorical Approach to Crisis Communication, Mahwah, NJ and London, Lawrence Erlbaum Associates, 2004.

Nakra P., "Corporate reputation management: 'CRM' with a strategic twist?", Public Relations Quarterly, 45, 2000, pp. 35-42.

Pander Maat H., "How promotional language in press releases is dealt with by journalists: genre mixing or genre conflict?", Fournal of Business Communication, 44, 1, 2007, pp. 59-95.

Reber B.H. "Avow or avoid. The public communication strategies of Enron and Worldcom”, Fournal of Promotion Management, 12, 3/4, 2006, pp. 215-239.

Sleurs K., Jacobs G., Van Waes L., "Constructing Press Releases, Constructing Quotations. An Ethnographic Perspective on Press Releases", Fournal of Sociolinguistics, 7, 2, 2003, pp. 192-212.

Sleurs K., Jacobs G. "Beyond Preformulation: An Ethnographic Perspective on Press Releases", Fournal of Pragmatics, 37, 2005, pp. 1251-1273.

Sturges D.L., "Communicating through crisis: A strategy for organizational survival", Management Communication Quarterly, 7, 3, 1994, pp. 297-316.

Swales J.M., Genre Analysis, Cambridge, Cambridge University Press, 1990.

Virtanen T. and Halmari H., "Persuasion across genres. Emerging perspectives" in Halmari H., Virtanen T. (eds.) Persuasion across genres. A linguistic approach, Amsterdam/Philadelphia, John Benjamins, 2005, pp. 3-24. 